\title{
Bovine Ephemeral Fever pada ternak sapi potong di Kabupaten Gunungkidul, Yogyakarta (Case Report)
}

\author{
Alfarisa Nururrozi, Mulya Fitranda, Soedarmanto Indarjulianto dan Yanuartono \\ Departemen Ilmu Penyakit Dalam, Fakultas Kedokteran Hewan Universitas Gadjah \\ Mada, Jl. Fauna No. 2 Karangmalang Yogyakarta 55281
}

Corresponden author: alfarisa.nururrozi@gmail.com

\begin{abstract}
Bovine Ephemeral Fever (BEF) or three days sickness is one of the most common disease in cattle. The disease is caused by rhabdoviridae virus transmitted through mosquito as a vectors. This paper aims to determine the incidence of BEF cases in Gunungkidul district, Yogyakarta. Diagnoses BEF based on information collected through the anamnesis from owner and the results of clinical examination. $134(48 \%)$ from 277 cows were examined in the Gunungkidul district period October-November 2016 diagnosed BEF. Clinical signs were found consist of anorexia 111 cases (34\%), hyperthermia 99 cases (31\%), lameness 42 cases (13\%), cow downer 31 cases (10\%), nasal discharge 35 cases (11\%) and hypersalivation 6 cases (2\%). Bovine Ephemeral Fever mayority reported on the second day of the disease progression by 67 cases $(42 \%)$. The most common therapy used combinations of antipyretics, antibiotics and vitamins were 45 cases $(33 \%)$. Based on the information from the farmers, the treatment has given good results and absence of the absence of post-treatment recurrence.
\end{abstract}

Keywords: Bovine ephemeral fever, cattle, Gunungkidul

\section{PENDAHULUAN}

Gunungkidul memiliki potensi peternakan sapi potong lokal jenis peranakan ongole (PO) atau yang biasa disebut sapi putih oleh masyarakat. Tingginya jumlah ternak sapi PO yang mencapai 147.198 ekor pada tahun 2014 (Badan Pusat Statistik, 2015) menjadikan daerah ini membutuhkan penanganan cermat terkait masalah kesehatan ternak (Badan Pusat Statistik, 2015). Bovine ephemeral fever (BEF) adalah salah satu penyakit yang paling banyak menyerang ternak sapi khususnya di daerah Gunungkidul. Penyakit BEF sangat sangat dipengaruhi curah hujan, ketinggian wilayah, populasi ternak, dan keberadaan vektor

penyakit (Walker, 2013; Kirkland, 2016).
Bovine ephemeral fever disebabkan oleh virus RNA beruntai tunggal (ssRNA) sense-negatif genus Ephemerovirus yang termasuk famili Rhabdoviridae (Barigye et al., 2016). Penyakit BEF sering juga disebut 'three days sickness', stiff sickness, dengue fever of cattle, bovine epizootic fever dan lazy man's disease (Walker, 2013; Kirkland, 2016). Menurut $\mathrm{He}$ et al. (2016), vaksinasi menggunakan protein ini dapat melindungi sapi dari infeksi. Program vaksinasi hingga saat ini belum diterapkan di Kabupaten Gunungkidul. Penyakit BEF ditularkan melalui artropoda seperti nyamuk Cullicoides spp, Culex annulirostris, Anopheline dan Culicine (Walker, 2013; Kirkland, 2016). Cullicoides yang terinfeksi dapat menyebarkan penyakit mencapai jarak 
$2.000 \mathrm{~km}$. Penularan melalui kontak langsung ataupun muntah tidak pernah dilaporkan sebelumnya (Walker, 2013; Kirkland, 2016).

Penyakit BEF lebih sering terjadi pada musim hujan untuk daerah tropis dan musim panas hingga awal musim semi untuk daerah subtropis, sedangkan pada musim dingin tidak ditemui. Bovine ephemeral fever dilaporkan terdapat di daerah Asia, Timur Tengah, Australia dan Afrika (Geoghegan et al., 2014), tetapi tidak ditemukan di Amerika Utara dan Eropa (Barigye et al., 2016). Tingkat morbiditas mencapai $80 \%$ dan mortalitas 1-2\% (Yeruham et al., 2007; Walker, 2014).

Hewan yang terinfeksi akan menunjukkan gejala klinis seperti demam tinggi hingga $40^{\circ}-42^{\circ} \mathrm{C}$, penurunan nafsu makan, leleran pada hidung dan mata, hipersalivasi, penurunan produksi susu secara mendadak, kepincangan yang biasanya terlihat pada hari kedua, menggigil, serta kekakuan otot (Ting et al., 2016; Kirkland, 2016). Jika tidak ditangani dengan baik dapat berakibat kematian pada sapi. Diagnosa berdasarkan gejala klinis dan waktu perjalanan penyakit yang singkat sekitar 3 hari (Walker, 2014).

Laporan kasus ini ditulis dilatar belakangi karena tingginya populasi ternak dan insidensi penyakit BEF di Gunungkidul. Dengan mengetahui tingkat kejadian kasus, gejala penyakit yang ada, dan respon pengobatan yang diberikan, diharapkan dapat memberikan informasi kepada petugas kesehatan hewan dalam penanganan kasus BEF. Penanganan yang tepat tentu akan meningkatkan keberhasilan pengobatan, sehingga mencegah adanya kematian sapi.

\section{MATERI DAN METODE}

Pada studi kasus ini digunakan metode pengumpulan data dari hasil anamnesa peternak dan pemeriksaan klinis ketika penanganan kasus. Kasus BEF yang dianalisa adalah kasus yang terjadi periode Oktober hingga Desember 2016. Ambulatoir yang terkumpul dari hasil pelayanan kesehatan hewan di empat UPT Puskeswan Gunungkidul dipilih yang menunjukkan diagnosa BEF dan dibahas secara retrospektif.

Gejala klinis dan perjalanan penyakit pada sapi diamati untuk menentukan tingkat kejadiannya. Terapi yang diberikan dibahas berdasarkan tingkat keberhasilan pengobatan. Data kemudian ditampilkan ke dalam diagram lingkaran untuk melihat persentase dan persebarannya secara ringkas. Analisa hasil dilakukan secara deskriptif dengan membandingkan data dari keempat UPT Puskeswan yakni Kecamatan Nglipar, Karangmojo, Patuk, dan Panggang.

\section{HASIL DAN PEMBAHASAN}

Sapi yang diamati secara keseluruhan merupakan sapi peranakan hasil persilangan, dan sebagian besar adalah jenis Peranakan Ongole (PO). Kandang pemeliharan konvensional dengan jumlah populasi 1-3 ekor setiap kandang . Dari total 277 sapi yang ditangani, jumlah kejadian BEF diketahui sebanyak 134 kasus (48\%). Kejadian tertinggi ditemukan pada UPT Nglipar yakni sebanyak 47 kasus, diikuti UPT Karangmojo sebanyak 42 kasus, UPT Panggang 42 kasus, dan UPT Patuk sebanyak 25 kasus (Gambar 1).

Tingginya kejadian BEF di Kecamatan Nglipar kemungkinan berhubungan dengan topografi wilayah yang berbukit-bukit dengan tingkat curah hujan paling tinggi diantara wilayah lainnya. Pada bulan basah atau musim penghujan yang dimulai pada bulan Oktober-November, biasanya akan terjadi peningkatan jumlah vektor pembawa penyakit BEF yakni artropoda seperti 
nyamuk yang dapat terbang bersama

pemeliharaan.

angin dan banyak diamati di kandang

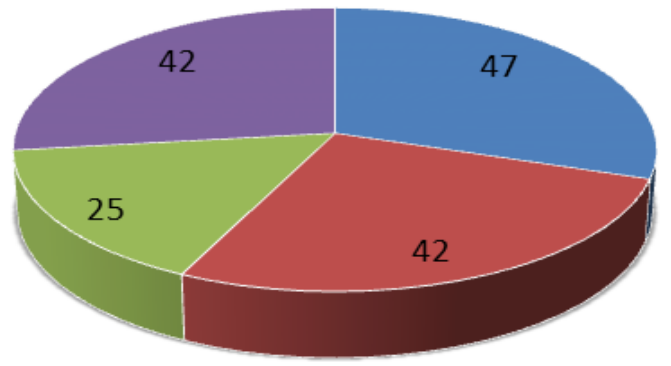

- Kecamatan Nglipar

- Kecamatan Karangmojo

- Kecamatan Patuk

- Kecamatan Panggang

Gambar 1. Diagram persebaran kasus BEF di Puskeswan Gunungkidul.

Gejala klinis yang paling banyak terlihat adalah hilangnya nafsu makan dan minum sebanyak 111 ekor sapi, diikuti dengan hipertermi (mencapai 41, $5^{\circ}$ C) sebanyak 99 ekor, kemudian pincang ekstremitas cranial maupun caudal sebanyak 42 ekor, ambruk 31 ekor, leleran nasal 35 ekor dan hipersalivasi sebanyak 6 ekor (Gambar 2).

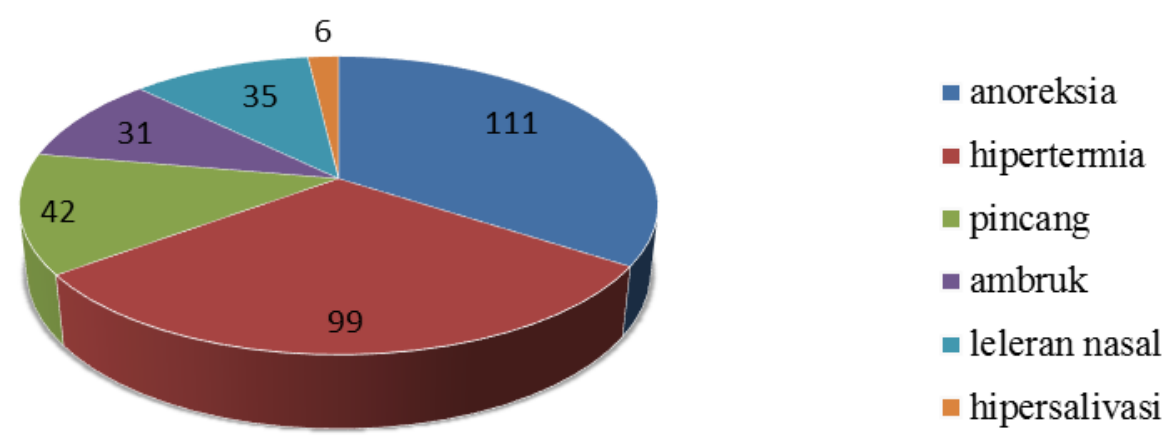

Gambar 2. Diagram gejala klinis BEF yang sering teramati di UPT Nglipar, Karangmojo, Patuk dan Panggang.

Hilangnya nafsu makan dan minum (anoreksia) kemungkinan disebabkan oleh terjadi hipertermi pada tubuh yang menagganggu selera makan dan minum ternak. Kirkland (2016) menyebutkan pada beberapa kejadian juga dilaporkan bahwa terjadi pembengkakan pada esofagus yang menyebabkan sapi tidak nyaman untuk makan karena kesulitan menelan. Virus juga dapat mengganggu sistem syaraf dalam pengontrolan penelanan, sehingga dapat mempengaruhi masuknya makanan, air ataupun saliva ke pulmo dan menyebabkan pneumonia. Hal tersebut juga dapat dikaitkan dengan gejala hipersalivasi sebagai respon adanya gangguan pada saluran pencernaan atas. Meningkatkan suhu tubuh sapi sebagai respon terhadap perlawanan virus yang menginfeksi dan menyebabkan leleran nasal bening hingga serous (Walker, 2014). Tremor extremitas baik cranial maupun caudal juga terjadi dan melanjut kepada kekakuan hingga kepincangan dan menyebabkan sapi 
menjadi malas bergerak. Kepincangan pada salah satu kaki merupakan ciri utama yang dapat diamati pada kejadian $\mathrm{BEF}$, tapi hanya akan terlihat pada hari kedua berjalannya penyakit (Kirkland, 2016).

Penanganan penyakit lebih banyak dilakukan saat penyakit sudah berjalan selama 2 hari, yakni dengan ditandai kepincangan ekstremitas cranial maupun caudal hingga ambruk. Berdasarkan data ambulatoir, diketahuin sebanyak 67 ekor (49\%) sapi mengala-

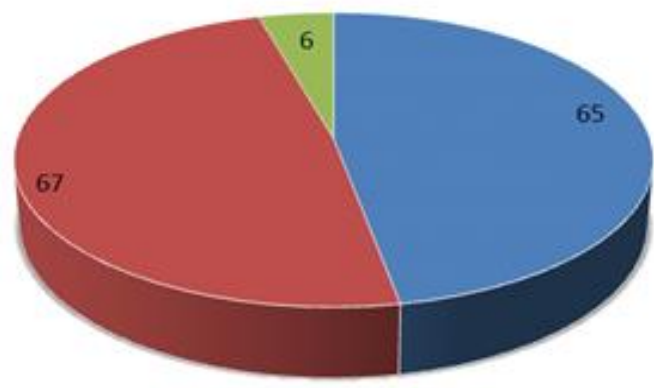

mi kepincangan (Kirkland, 2016) bahkan hingga ambruk dan nafsu makan serta minum tidak ada. Sedangkan sebanyak 65 ekor (47\%) penyakit masih berjalan pada hari pertama yakni ditandai dengan nafsu makan dan minum yang sudah mulai tidak ada tetapi belum terjadi kepincangan atau ambruk dan 6 ekor $(4 \%)$ telah memasuki hari ketiga yakni ditandai dengan nafsu makan dan minum sudah mulai ada dan tidak menglami kepincangan.

Gambar 3. Diagram perjalanan penyakit ketika ditangani berdasarkan gejala klinis BEF yang diamati di UPT Nglipar, Karangmojo, Patuk dan Panggang.

Terapi yang diberikan terdiri dari berbagai kombinasi antara antipiretik, antibiotik, antihistamin dan vitamin. Berdasarkan terapi yang digunakan pada keempat UPT diketahui kombinasi antipiretik, antibiotik dan vitamin yang paling banyak digunakan dari keseluruhan kombinasi yakni pada sebanyak 45 kasus (33\%), diikuti dengan kombinasi antipiretik dan antibiotik sebanyak 31 kasus (22\%). Kemudian kombinasi lainnya seperti antipiretik, antihistamin dan vit- amin sebanyak 20 kasus (14\%) diikuti kombinasi antipiretik dan vitamin sebanyak 19 kasus (14\%). Sedangkan kombinasi lainnya seperti antibiotik dan antihistamin juga diberikan sebanyak 8 kasus (6\%), kombinasi antihistamin dan vitamin sebanyak 6 kasus (3\%), kombinasi paling lengkap mencakup antipiretik, antibiotik, antihistamin dan vitamin diberikan pada 2 kasus (1\%) serta 1 kasus (1\%). Bahkan pemberian vitamin saja juga diberikan pada 3 kasus (2\%).

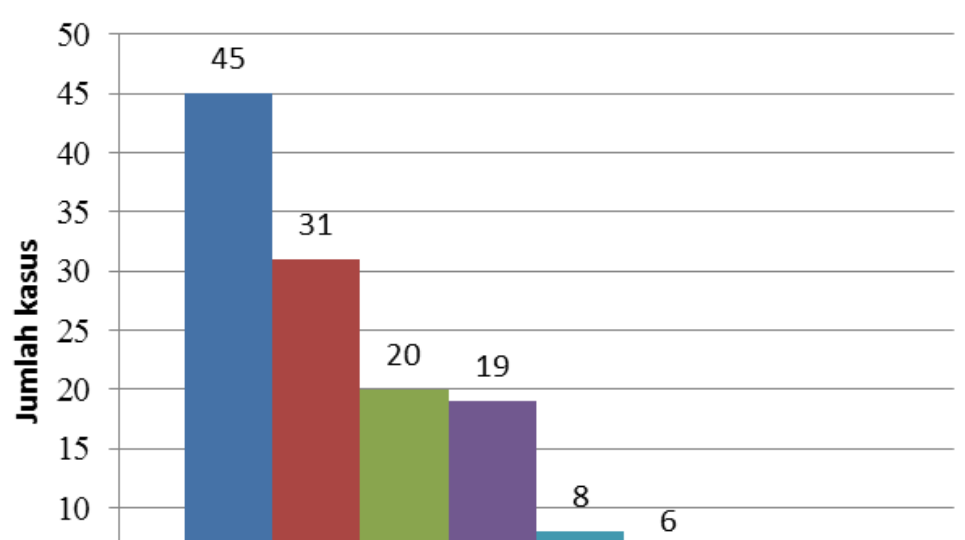

antipiretik, antibiotik, vitamin

antibiotik dan antipiretik

antipiretik, antihistamin, vitamin

antipiretik dan vitamin

antibiotik dan antihistamin

antihistamin dan vitamin

antipiretik, antibiotik, antihistamin, vitamin 
Gambar 4. Diagram kombinasi terapi yang digunakan pada penganganan BEF di UPT Nglipar, Karangmojo, Patuk dan Panggang.

Kombinasi antipiretik, antibiotik dan vitamin memberikan tingkat kesembuhan yang baik berdasarkan informasi dari petugas yang mendapat laporan dari peternak pasca penanganan dengan tidak adanya kejadian berulang. Antipiretik yang biasa digunakan mengandung dypirone sebagai anti inflamasi non steroid (NSAID) dan lidocaine sebagai analgesik juga antispasmodik. Dypirone bekerja dengan menghambat secara reversibel enzim siklooksigenase-1 dan 2, dan mengakibatkan penurunan produksi prekursor prostaglandin (COX-1 dan 2) yang diketahui sebagai mediator radang sehingga proses keradangan bisa dikurangi. Sebagai analgesik dengan efek sedasi lokal, lidocaine akan mengurangi rasa sakit dengan menutup reseptor sakit pada bagian tubuh yang sakit (Lee, 2007).

Antibiotik yang biasa digunakan diantaranya oksitetrasiklin, penisilinstreptomisin, dan trimetropin-sulfa. Antibiotik spektrum luas dengan kandungan oksitetrasiklin dan sulfadiazine lebih sering digunakan karena mampu mencegah infeksi sekunder bakteri secara luas. Oksitetrasiklin bekerja menghambat pertumbuhan bakteri atau bakteriostatik, sedangkan prparat sulfa yang mengandung sulfadiazine dan trimertrophine bekerja sinergis sebagai bakterisidal atau membunuh bakteri.
Secara umum bakteriostatik bekerja dengan mempengaruhi sintesis protein, sedangkan bakterisid bekerja dengan mempengaruhi pembentukan dinding sel atau permeabilitas membran sel (Baggot, 2001).

Antihistamin diberikan untuk menghalangi resptor kinerja senyawa histamin tubuh sehingga keradangan bisa dikurangi.Vitamin yang biasa diugunakan adalah Vitamin B1, BKompleks, dan multivitamin. Keseluruhan vitamin yang diberikan secara umum mampu memberikan suplai energi tubuh untuk mengatasi gejala kelemahan yang sering ditemui pada penderita $\mathrm{BEF}$ akibat tidak adanya makanan yang masuk untuk kemudian dikonversi menjadi energi (Baggot, 2001). Senyawa ATP yang terdapat pada multivitamin membantu pasokan tenaga. Efek syarafi moloeh vitamin B1 akan membantu dalam kepincangan ekstremitas sapi dan gangguan syaraf lainnya (Plumb, 2008).

\section{KESIMPULAN}

Dari hasil anamnesa peternak dan pemeriksaan gejala klinis di empat UPT Puskeswan Nglipar, Karangmojo, Patuk dan Panggang pada periode pelayanan kesehatan ternak 31 Oktober hingga 25 November diketahui tingkat kejadian BEF sangat tinggi mencapai 48\% yakni 134 kasus dari 277 kasus berbagai macam penyakit yang di- 
tangani pada sapi, dengan kejadian paling tinggi terjadi di Kecamatan Nglipar yang mencapai 35\% yakni 47 kasus. Gejala klinis paling banyak ditemui adalah anoreksia (34\%) diikuti dengan hipertermi (31\%), kepincangan (13\%) bahkan ambruk (10\%), leleran nasal (11\%) dan hipersalivasi (2\%).Penyakit ditangani paling banyak pada hari kedua perjalanan penyakit yakni sebanyak $42 \%$. Sedangkan terapi yang paling banyak digunakan adalah kombinasi antipiretik, antibiotik dan vitamin sebanyak $33 \%$ dan telah memberikan hasil baik tanpa kejadian berulang berdasarkan informasi peternak pasca penanganan.

\section{DAFTAR PUSTAKA}

Badan Pusat Statistik. 2015. Gunugkidul dalam angka 2015. Badan Pusat Statistik Gunungkidul. Hal 199.

Barigye R., Melville L.F., Davis S., Wlash S., Hunt N., dan Hunt R. 2016. Kinetics of selected plasma cytokines during innateadaptive immune response transition in adult cattle infected with bovine ephemeral fever virus. Vet. Microbiol Vol 186: hal 111-116.

Baggot, J.D. 2001. The Physiological Basis of Veterinary Clinical Pharmacology. Wiley Blackwell Science. New York

Geoghegan, J.L., Walker, P.J., Duchemin, J.B., Jeanne, I., Holmes, E.C., 2014. Seasonal drivers of the epidemiology of arthropodborne viruses in australia. PLoS Negl. Trop. Dis 8: hal 3325.

He CQ., Liu YX., Wang HM., Hou PL, He HB., Ding NZ. 2016. New genetic mechanism, origin and population dynamic of bovine ephemeral fever virus. Vet. Microbiol Vol 182: hal 50-56.
Kirkland P. 2016. Bovine ephemeral fever: three day sickness. The Center for Food Security and Public Health. Ames, Iowa. Hal 1-4

Lee L. 2007. Local anesthesia \& analgesia. Dalam : Veterinary Surgery I. 7412.

Plumb DC. 2008. Plumb's veterinary drug handbook. Sixth Edition. Blackwell Publishing, New York.

Ting LJ., Lee MS., Lin YH., Cheng MC., Lee F. 2016. Invasion of exotic bovine ephemeral fever virus into taiwan in 2013-2014. Vet. Microbiol Vol 182: hal 1517.

Walker PJ. 2013. Bovine ephemeral fever: cyclic resurgence of a climatesensitive vector-borne disease. Microbiol. Aust : hal 4142.

Walker PJ. 2014. The merck veterinary manual: bovine ephemeral fever. http://www.merckvetmanual.co $\mathrm{m} / \mathrm{mvm}$ /generalized_conditions/ bo-

vine_ephemeral_fever/overview _of_bovine_ephemeral_fever.ht ml diakses pada 1 Januari 2017.

Yeruham I., Gur Y., Braverman Y. 2007. Retrospective epidemiological inverstigation of an outbreak of bovine ephemeral fever in 1991 affecting dairy cattle herds on the mediteranean coastal plain. The Veterinary Journal Vol 173: hal 190-193. 